\title{
Social Exclusion Under the Auspices of the State? Case Study of Social Exclusion, Ethnicity and Migration in Osoblaha Region ${ }^{1}$
}

\author{
Dušan JANÁK, jr. - Jan BEZDĚK - Václav WALACH
}

\author{
Centrum empirických výzkumů, Fakulta veřejných politik, Slezská univerzita v Opavě \\ Centre of Empirical Research, Faculty of Public Policies, Silesian University in Opava, \\ Hradecká 665/17, 74601 Opava, Czech Republic \\ janak@fvp.slu.cz \\ Centrum empirických výzkumů, Fakulta veřejných politik, Slezská univerzita v Opavě \\ Centre of Empirical Research, Faculty of Public Policies, Silesian University in Opava, \\ Hradecká 665/17, 74601 Opava, Czech Republic \\ bezdek.jan@email.cz \\ Fakulta sociálních studií, Masarykova univerzita v Brně \\ Faculty of Social Studies, Masaryk University in Brno \\ Joštova 218/10, 60200 Brno, Czech Republic \\ 219253@mail.muni.cz
}

\section{Introduction}

The topic covers social exclusion in a frontier rural region and influence of migration on its deepening. The specific goal consists in analysing the character of social exclusion as a social problem in the Osoblaha Region and in identifying the mechanisms producing it, from the perspective of local population. We rely on the empirical sociological research that was performed in that north-eastern point of the Bruntál District in 2013 in order to map the local socio-economic inequalities and potential regional development. ${ }^{2}$

The following text is divided into three parts. The first part discusses the concept of social exclusion a "multidimensional system of disadvantage". ${ }^{3}$ We specify the basic indicators of social exclusion - unemployment, education, community facilities and transport services - to analyse them further. The second section describes the methods applied in empirical research. We have followed the integrated research strategy following the comprehensive understanding of a specific phenomenon both by combining the quantitative and qualitative data and by engaging a broad spectrum of research actors. ${ }^{4}$

The last part is devoted to the analysis of our findings. Its structure observes the double conceptualization of spatial dimension of social exclusion. The spatial exclusion refers both

1 The study was supported by project NAKI (The legal circumstances of minorities) no. DF12P01OVV013.

2 For more details, see: JANÁK, Dušan - PILÁT, Miroslav - BEZDĚK, Jan: Rozdělování sociálních nerovností pod patronací státu. Situační analýza Osoblažska a možností jeho socioekonomického rozvoje, Opava 2014.

3 RŮŽIČKA, Michal - LUPTÁK, Ĺubomír: Tě̌̌ební limity prolomeny: Extrakce ekonomického a politického kapitálu z romského ghetto, in: LUPTÁK, Ĺubomír a kol.: Neoliberalismus a marginalita: studie z českého reálkapitalismu, Brno 2013, 192.

4 LOUČKOVÁ, Ivana: Integrovaný př́stup v sociálně vědním výzkumu, Praha 2010. 
to specific characteristics of environment, causing social disadvantage of the inhabitants, and to concentration of socially excluded persons in a specific time and space. In a certain sense, spatial exclusion can be understood as exclusion characterized by two degrees of intensity. The second degree of social exclusion has a character of materially and symbolically delimited localities within a socially excluded region, i.e. a region characterized by high unemployment, low education level and bad transport services. Thus as soon as the position of the Osoblaha Region is shortly described, attention will be focused on spatial characteristics of that region and subsequently on local concentrations of socially excluded persons.

We would like to use this case study to contribute to the discussion on a phenomenon, not sufficiently examined in the Czech context so far, consisting in the influence of the disadvantage represented by specific environment characteristics on the transformation of the population structure due to migration. On one hand, such characteristics are involved in strengthening the migration of rather educated population able to work from the Osoblaha Region to urban centres of the republic, while on the other hand, they contribute to create conditions for arrival of socially excluded persons, particularly Romani people who use the opportunity of relatively cheap housing. In such way, localities perceived by long-term residents as source of social tension originate. ${ }^{5}$

We present the main finding as the need to analyse the role of the state in shaping social exclusion. From the perspective of our respondents, the public policies implemented in the past have caused the current situation of the region. The post-war displacement of the Germans from Czechoslovakia, the collectivization of agriculture combined with resettlement of frontier regions, subsequent privatization of agriculture in the 1990s, but also the current settings of the subsidy policy for agriculture, current redistribution mechanisms of the welfare state, particularly in the region of housing - these are the most important historical moments that, in their opinion, have opened the way to social exclusion of the region under research.

\section{Overview of literature and conceptual foundations}

Social exclusion constitutes a significant social problem of late-modern societies. Although the mechanism of replacing of so called deviant groups is characteristic to all human societies, as it helps to strengthen their inner cohesion by their identification and sanctioning, the liberal-democratic regimes primarily consider it negative. Exclusion of specific social segments is deemed violation of the principle of human rights on which the legitimacy of such regimes is based. ${ }^{6}$ In this article, we also approach social exclusion as a social problem that could be primarily solved by the state apparatus.

The very concept of social exclusion has origin in the discourse of social policy of Western

5 Compare: DRBOHLAV, Dušan - RÁKOCZYOVÁ, Miroslava: Social Impact of Emigration and Rural-Urban Migration in Central and Eastern Europe. Final Country Report: Czech Republic [online] 2012 [cit. 1. 12. 2014], dostupné z: http://ec.europa.eu/social/BlobServlet?docld=8850\&langld=en.

6 MAREŠ, Petr: Marginalizace, sociální vyloučení, in: Menšiny a marginalizované skupiny v České republice, SIROVÁTKA, Tomáš (ed.), Brno 2002, 9-24. 
European states. Petr Mareš and Tomáš Sirovátka7 see in it the "effort to retell the fundamental social problems of today's Europe in a language that shifts attention from vertical inequalities approached in traditional terms of social stratification ('up' versus 'down' or wealth / power versus poverty / powerlessness or privileges versus deprivation with emphasis on redistribution) to horizontal inequalities ('inside' versus 'outside' or separation versus participation with emphasis on incorporation and integration)," although one of the main reasons why "to be inside" keeps consisting in the effort "not to be down". 8

Although there are different political discourses on social exclusion, ${ }^{9}$ the generally widespread approach is based on a diagnosis establishing the causes of exclusion out of control of the excluded persons and on the adequate treatment through public policies, adopted, within unification of legislation, by the European Union member states and by their academic communities through subsidy programs. ${ }^{10}$

In view of the statements presented above, we understand social exclusion, in compliance with the definition used in state-administrative discourse, as a "process during which individuals or whole groups are displaced to the margin of the society and their access to resources and opportunities, commonly available to the other members of the society, is restricted or reduced"..$^{11}$ The most frequent resources needed to full participation in public matters are, in the first place, described as "employment, housing, social protection, health care and education". ${ }^{12}$ Hence, social exclusion is not only a matter of poverty but of all forms of disadvantage that displace the affected persons to or beyond the margin of the society.

Scholars deem the multidimensional character to be the main contribution of the concept of social exclusion. ${ }^{13}$ The economic and spatial dimensions are considered crucial in this context. ${ }^{14}$ As for the first dimension, we mean the exclusion through insufficient income, particularly marginalization in the labour market and the resulting poverty of the individual and the individual's household. Spatial exclusion refers to concentration of socially excluded persons in a specific place at a specific time on one hand and to the status of exclusion of

7 MAREŠ, Petr - SIROVÁTKA, Tomáš: Sociální vyloučení (exkluze) a sociální začleňování (inkluze) - koncepty, diskurz, agenda, in: Sociologický časopis/Czech Sociological Review, 44, 2008, 2, 273.

8 Sometimes, these social problems are called new social risks emerging together with the crisis of the post-war welfare state in the 1970s and with coping with that crisis in intentions of neoliberalism in the subsequent decades. See: KELLER, Jan: Nová sociální rizika a proč se jim nevyhneme, Praha 2011; WINKLER, Jiří - KLIMPLOVÁ, Lenka: Nová sociální rizika na trhu práce a potřeby reformy české veřejné politiky, Brno 2010.

9 LEVITAS, Ruth: The Inclusive Society? Social Exclusion and New Labour, Basingstoke 2005.

10 Compare: GERBERY, Daniel - DŽAMBAZOVIČ, Roman: Inovativne orientácie v sociálnej politike: Perspektíva sociálnej inklúzie, Bratislava 2011; GORDON, David: History and Development of Social Exclusion and Policy, in: Multidisciplinary Handbook of Social Exclusion Research, ABRAMS, Dominic - CHRISTIAN, Julie - GORDON, David (eds.), Chichester 2007, 193-210

11 Strategie sociálního začleňování 2014-2020, Praha 2014, 4.

12 Ibidem

13 MILLAR, Jane: Social Exclusion and Social Policy Research: Defining Exclusion, in: Multidisciplinary Handbook of Social Exclusion Research, ABRAMS, Dominic - CHRISTIAN, Julie - GORDON, David (eds.), Chichester 2007, 1-16; TOUŠEK, Ladislav: Kultura chudoby, underclass a sociální vyloučení, in: „Romové" v osidlech sociálního vyloučení, HIRT, Tomáš - JAKOUBEK, Marek (eds.), Plzeň 2006, 306-315.

14 RŮŽIČKA, Michal - TOUŠEK, Ladislav: Sociální exkluze: její prostorové formy a měnící se podoby, in: ŠUBRT, Jiř́ a kol.: Soudobá sociologie VI (Oblasti a specializace), Praha 2014, 117-141. 
a specific territory due to characteristics like dysfunctional local labour market and lack of job opportunities, lack and low quality of education system, inaccessible medical care, bad transport services and low level of community facilities. ${ }^{15}$

In empirical research, such double approach is reflected in splitting of the area of interest in socio-spatial differentiation. ${ }^{16}$ One approach researches the disadvantage level of specific, predominantly rural regions that have remained apart from the economic development and are affected by emigration of population with usually higher education level. ${ }^{17}$ In the Czech Republic, such an approach is represented e.g. by the work by Jiří Musil and Jan Müller ${ }^{18}$ and by other sociologists of rural regions or social geographers. ${ }^{19}$

On the other hand, social scientists focus on sub/urban localities where specific, usually ethnically stigmatized groups concentrate. ${ }^{20}$ In the Czech conditions, they are known as socially excluded localities with above-average representation of Romani people among

15 MAREŠ, Petr: Faktory sociálního vyloučení, Praha 2006, 10. Compare: MAREŠ, Petr: Prostorové aspekty sociální exkluze, in: MAREŠ, Petr - HORÁKOVÁ, Markéta - RÁKOCZYOVÁ, Miroslava: Sociální exkluze na lokální úrovni, Praha 2008, 9-42; MUSIL, Jiř́: Regionální a místní formy sociálního vyloučení a jak jim čelit - problém vnitřních periferií v České republice, in: Sociální vyloučení a sociální politika, SIROVÁTKA, Tomáš (eds.), Brno 2006, 25-40.

16 The splitting is of course not absolute. Regarding papers combining both approaches (e.g. RŮŽlČKA, Michal: Časoprostorové a infrastrukturní aspekty procesu sociální exkluze, in: Sociologický časopis/Czech Sociological Review, 47, 2011, 2, 273-295), it must be therefore emphasized that it rather expresses some dominant tendencies within the research of spatial inequalities and social exclusion. For overview, see: MACEŠKOVÁ, Marie - OUŘEDNÍČEK, Martin - TEMELOVÁ, Jana: Sociálně prostorová diferenciace v České republice: implikace pro veřejnou (regionální) politiku, in: Ekonomický časopis, 57, 2009, 7, 700-715.

17 BURTON, Linda M. - GARRETT-PETERS, Raymond - MAJOR EASON, John: Morality, Identity, and Mental Health in Rural Ghettos, in: Communities, Neighborhoods, and Health. Expanding the Boundaries of Place, BURTON, Linda M. - KEMP, Susan P. - LEUNG, Manchui - MATTHEWS, Stephen A. - TAKEUCHI, David. T. (eds.), New York 2011, 91-110; BERTOLINI, Paola - MONTANARI, Marco - PERAGINE, Vito: Poverty and Social Exclusion in Rural Areas. Final Study Report [online]. Brussels, Luxembourg: Directorate-General for Employment, Social Affairs and Equal Opportunities, 2008 [cit. 1. 12. 2014]. Dostupné z: http://ec.europa.eu/ social/BlobServlet?docld=2087\&langld=en; SHLUCKSMITH, Mark: Class, Power and Inequality in Rural Areas: Beyond Social Exclusion?, in: Sociologia Ruralis, 52, 2012, 4, 377-397; SHLUCKSMITH, Mark: Social Exclusion in Rural Areas: A Review of Recent Research, London 2004; STEWART, Kitty: Monitoring Social Inclusion in Europe's Regions, in: Journal of European Social Policy, 13, 2003, 4, 335-356.

18 MUSIL, 2006, 25-40; MUSIL, Jiří - MÜLLER, Jan: Vnitřní periferie v České republice jako mechanismus sociální exluze, in: Sociologický časopis/Czech Sociological Review, 44, 2008, 2, 321-348.

19 E.g. BLAŽEK, Jiř́ - CSANK, Pavel: Nová fáze regionálního rozvoje v ČR?, in: Sociologický časopis/Czech Sociological Review, 43, 2007, 5, 945-965; HAMPL, Martin: Regionální diferenciace současného socioekonomického vývoje v České republice, in: Sociologický časopis/Czech Sociological Review, 43, 2007, 5, 889-910; HAVLíČEK, Tomáš - CHROMÝ, Pavel - JANČÁK, Vít - MARADA, Miroslav: Vybrané teoreticko-metodologické aspekty a trendy geografického výzkumu periferních oblastí, in: Problémy periferních oblastí, NOVOTNÁ, Marie (ed.), Praha 2005, 6-24; KUBEŠ, Jan - KRAFT, Stanislav: Periferní oblasti jižních Čech a jejich sociálně populační stabilita, in: Sociologický časopis/Czech Sociological Review, 47, 2011, 4, 805-829; MAJEROVÁ, Věra: Český venkov 2008 proměny venkova, Praha 2009; PERLíN, Radim - KUČEROVÁ, Silvie - KUČERA, Zdeněk: Typologie venkovského prostoru Česka, in: Geografie, 15, 2010, 2, 161-187; TEMELOVÁ, Jana - NOVÁK, Jakub - POSPÍŠILOVÁ, Lucie - DVOŘÁKOVÁ, Nina: Každodenní život, denní mobilita a adaptační strategie obyvatel v periferních lokalitách, in: Sociologický časopis/Czech Sociological Review, 47, 2011, 4, 831-858; etc.

20 DAVIS, Mike: Planet of Slums, London 2007; MASSEY, Douglas S. - DENTON, Nancy A.: American Apartheid: Segregation and the Making of the Underclass, Cambridge 1993; MUSTERD, Sako: Social and Ethnic Segregation in Europe: Levels, Causes, and Effects, in: Journal of Urban Affairs, 27, 2005, 3, 331-348; SIBLEY, David: Geographies of Exclusion: Society and Difference in the West, London, New York 1995; WACQUANT, Loïc: Urban Outcasts. A Comparative Sociology of Advanced Marginality, Cambridge 2008. 
the population..$^{21}$ In 2006, more than 300 such localities were identified in 167 municipalities in total. ${ }^{22}$ At present, the exact figure is not known. Nevertheless, according to qualified estimate, it keeps increasing. ${ }^{23}$

In this article, the two orientations present at different geographic levels meet each other. While the first serves us to draw particularly specific indicators of social exclusion of the region, the second lends us the term "socially excluded locality" to conceptualize the concentration of socially excluded persons within the given region. The analysable indicators are: degree and character of unemployment, degree of education, quality of community facilities and transport services of the Osoblaha Region. Although other indicators could be identified as well, we consider the above stated indicators representative to outline the social exclusion of the region as a whole. ${ }^{24}$

Gabal's team delimits socially excluded Romani localities as an "area inhabited by a group whose members refer to themselves as Romani and/or are referred as Romani by their environment"; it applies that "it is not necessary at all that the Romani people constitute statistical majority in the given locality". ${ }^{25}$ As we will see below, the excluded Osoblaha localities are not inhabited only or predominantly by the Romani either. In the case such areas can be found in a region that, as a whole, meets the conditions of social exclusion due to its characteristics, and then socially excluded localities should be considered areas where such characteristics assume relatively higher values. In this sense, such localities are even more excluded in the context of the excluded region.

\section{Research method}

We have used the research design close to the integrated research strategy. ${ }^{26}$ It consists less in the use of quantitative and qualitative data collection and analysis techniques, which are relatively standard and generally recommended in the context of case studies ${ }^{27}$, than in a peculiar research procedure in which the researchers themselves, the research users and the researched persons are considered. The combination of methodical approaches and the use of varied techniques of construction of the data set bring much more abundant

21 BARŠOVÁ, Andrea: Problémy bydlení etnických menšin a trendy k residenční segregaci v České republice, in: Romové ve městě, VIIŠEK, Petr (ed.), Praha 2002, 3-42; GRYGAR, Jakub - STÖCKELOVÁ, Tereza: Příčiny a souvislosti stěhování vsetínských Romů z pavlačového domu č.p. 1336 v řijnu 2006, Brno 2007; HIRT JAKOUBEK, 2006; LUPTÁK, 2013; RU゚ŽIČKA, Michal: Urbanizace chudoby a etnicity v socialistickém a (post) socialistickém městě, in: Československé město včera a dnes: každodennost, reprezentace, výzkum, VACKOVÁ, Barbora - FERENČUHOVÁ, Slavomíra - GALČANOVÁ, Lucie (eds.), Červený Kostelec 2010, 137-158; ŠIMÍKOVÁ, Iva - VAŠEČKA, Imrich (eds.): Mechanismy sociálního vyčleňování romských komunit na lokální úrovni a nástroje integrace, Brno 2004.

22 Analýza sociálně vyloučených romských lokalit a absorpční kapacity subjektů působících v této oblasti, Praha 2006.

23 Compare: Strategie sociálního začleňování 2014-2020, Praha 2014, 62.

24 Compare: MAREŠ, 2006; RŮŽIČKA - TOUŠEK, 2014, 117-141.

25 Analýza sociálně vyloučených romských lokalit a absorpční kapacity subjektů působících v této oblasti, Praha 2006, 10.

26 LOUČKOVÁ, 2010.

27 FLYVBJERG, Bent: Case Study, in: The Sage Handbook of Qualitative Research, DENZIN, Norman K. LINCOLN, Yvonna S. (eds.), Thousand Oaks 2011, 301-316. 
information on the problem under research than relying upon one or another technique, although implemented in extensive form (e.g. implementation of fully representative questionnaire inquiry among the inhabitants or of in-depth interviews). Our effort knowingly continues the tradition of the Czech sociology that strives for comprehensive study of social phenomena. ${ }^{28}$

The main stage of data construction took place in two waves - in early June and early July 2013. From among the procedures assignable to the quantitative methodical paradigm, we used our own questionnaire inquiry on one hand and public and mediated data sources on the other hand. As for the questionnaire, the sample was created by combining the quota and deliberate selection. We specified the respondent's place of residence and its level of social exclusion as the basic quota. In the first case, we distinguished among four municipalities, i.e. Osoblaha, Slezské Pavlovice, Dívčí Hrad and Hlinka, while in the other case, in view of the research focus on the structure of labour market and economic potential of the region, we stuck to the criterion of reliance on social assistance, or unemployment, respectively. ${ }^{29}$ First, pilot research was implemented on a small sample of respondents, leading to partial modifications of the questionnaire sheet. 60 respondents participated in it; categories of people in productive age, marginalized in the labour market are overrated among them. ${ }^{30}$

The publicly available statistically data were drawn particularly from the Czech Statistical Bureau, but also from the Business / Trade Register and Land Registry. Different non-public statistics were offered to us at request by such institutions like the Czech Employment Office, or its Krnov and Osoblaha centres, respectively, Divisions of Social Affairs off the above stated municipalities, the Czech Police, elementary schools and kindergartens, citizens' associations (e.g. Althaia o.p.s.), as well as by municipalities that had performed questionnaire inquiry focused on analysis of social services. The quantitative logic was followed also by the evaluation of the "catalogue" of business intentions of local business persons with whom we made semi-structured interviews. ${ }^{31}$

The qualitative data body consisted of interviews with business persons, citizens and representatives of different institutions and of field observations. More than 50 interviews were conducted in total; they differed both in form and in duration. The core of our research relied on semi-structured interviews with local and non-local business persons 15 of them were done in July of the year in question (10 interviews with business persons

28 JANÁK, Dušan: Brněnská versus pražská sociologická škola: mýtus a skutečnost, in: Sociologický časopis/ Czech Sociological Revue, 49, 2013, 4, 577-602.

29 We included also citizens performing community service into this category; such a service is something in between employment acquired in the labour market and welfare state benefit.

30 The deliberate character of the selection and the relatively limited number of respondents does not allow generalization of our findings on the whole population of the Osoblaha Region, or of the four above stated municipalities, respectively. The representativeness cannot be quantified, and the low number of persons in the selection set does not allow more complex statistical analyses. Nevertheless, the sample is constructed to represent specific types of households meeting relevant social characteristics (threat of social exclusion, marginalization in labour market, large families and families with children, households of individuals, old residents and recent immigrants, etc.).

31 The catalogue was a list of business intentions created based on focus groups, in which Local Partnership members took place. The business persons assigned scores to individual intentions. 
active in the Osoblaha Region and five interviews with business persons active outside the region). ${ }^{32}$ In their selection, we tried to consider the different sizes from the perspective of the number of employees (from big companies to self-employed persons), the duration of activity in the locality (under five years, over five years, including a businessman who left the locality and a person preparing the business intention) and the type of production sphere (production, services, and agriculture). The interview duration varied between 90 and 210 minutes. The goal consisted in identifying the barriers and opportunities of socioeconomic development of the region.

Eight in-depth interviews were held with inhabitants of the Osoblaha Region (most of them came from socially excluded localities). One interview lasted about 60 minutes, and the interviews were aimed at capturing the life situation of the respondents in context of their social exclusion in the region. Last but not least, while processing the study, we often addressed additional questions to the representatives of local administrations, former and current mayors and municipal representatives, to representatives of the school system, municipal councils, employment office centres, the police, employees of the Krnov Micro Region and MAS, social services, as well as to members of the Employment and Economic Development working group and of other working groups of Local Partnership. We held more than 30 interviews of that kind, including interviews with participation of the inhabitants, e.g. workers of community services; the interviews lasted from several-minutes specifying phone inquiries to one-hour semi-structured interviews.

Observation constituted a relevant part of the research. We observed e.g. the furnishings of the households of the respondents or the appearance of public regions; we visited local agricultural businesses; we also took part in the discussions of the local authority of a selected municipality and in work meetings of Local Partnership in order to acquire information from the relevant local actors from different regions. As result, we acquired a relatively comprehensive idea of the socio-economic situation in the region, and the collected data contain even further analytical potential that was by far not exhausted by the submitted study.

\section{Main findings}

The Osoblaha Region, nicknamed Silesian Haná due to its agricultural character, is situated in the Bruntál District on the north-west of the Moravian-Silesian Land. From the perspective of the recently created typology of the Czech rural regions, it falls under the type of problematic recreational rural regions that disposes of considerable tourism potential but faces a high degree of unemployment, low educational index, low social cohesion and political apathy. ${ }^{33}$ Also the map of inner peripherals of the Czech Republic, the Osoblaha Region as a whole is highlighted in red, indicating peripheral status. ${ }^{34}$

Considerable degree of social exclusion at regional level is emphasized by Novák ${ }^{35}$ by

3210 respondents agreed to record the interview on the voice recorder; in the remaining cases, pre-printed schemes were used to record the notes.

33 PERLÍN - KUČEROVÁ - KUČERA, 2010, 180.

34 MUSIL, 2006, 35.

35 NOVÁK, Karel A.: Analýza prihlášky obce Osoblaha, Praha 2012, 4, part interviews 9. 
stating: „[A]ccording to the estimate of the Employment Office, 1500 inhabitants (including about 250 Romani persons) of the micro-region (administration district of authorized municipality of Osoblaha -7 municipalities), out of the 3500 , are endangered by poverty and social exclusion." Social exclusion is such a massive phenomenon in the Osoblaha Region that it threatens almost every second or third inhabitants. Individuals are not necessarily affected by the same problems (one has not had job in the long term, the second faces complications in transport to school of his children, the third is plagued by indebtedness, the fourth lives in a place without mobile phone signal, the fifth faces unbearable expenses for disposal of the septic tank of his small business, etc.); but all in all, we can speak of different displays of the same phenomenon typical to socially excluded regions.

The following subsections will first describe the current situation of social exclusion in the Osoblaha Region. At the level of regional characteristics, we will discuss the factors of unemployment, education and transport services; at local level, we will discuss social excluded localities from the perspective of type of property, composition of their population and their stigmatization. This description is generally performed considering their role in subjectively felt increase of social tension in the relevant region.

Subsequently, our attention will focus to historical and recent reasons of social exclusion articulated in the interviews with our respondents. The statements can of course not be understood as the objective representation of the reality. Yet, it is important to deal with them further, as they provide the researchers with historically shaped local understanding of the relevant issues and draw their attention to factors and relations that are quite specific in the relevant context.

\section{Regional and local: Two-degree spatial exclusion of the Osoblaha Region}

Seen through a prism of the spatial characteristics, the most significant component of social exclusion is the inadequate structure of the labour market. Unemployment is probably the most burning and most severe problem of the Osoblaha Region, or of the whole Bruntál District, respectively; for almost 20 years, they have been ranking in the top places of the unemployment charts of the Czech Republic with 8-12\% unemployed persons in the periods of season works, performed in most cases for the municipalities, and increasing between October and March.

Due to absence of statistical data from the Employment Office, caused by change of information systems, the last available statistical data by municipalities come from 2011, when the highest unemployment was reported in the municipality of Slezské Pavlovice $(46,7 \%)$ and in the municipality of Hlinka $(40,0 \%)$ in February of the year in question; the average unemployment of the whole region amounted to $28,2 \%$. On the contrary, the lowest unemployment is constantly reported in the municipality of Dívči Hrad (13,8 \%) and in the municipality of Osoblaha (18,6\%) in April 2011 when the average unemployment was $21,3 \%$. When comparing the above stated statistical data with the average unemployment degree in the relevant months within neighbouring areas, we can see that, as compared to the Albrechtice Region, the unemployment of the Osoblaha Region is by 9,1\% higher in February and by 6,1\% higher in April, and as compared to the Krnov Region, the 
unemployment of the Osoblaha Region is by $12,8 \%$ higher in February and by 6,9 \% in April. Let's add to the list of the statistical data of the unemployment degree from the Integrated Portal of MPSV that the average unemployment degree in the Moravian-Silesian Land amounted to $11,3 \%$ and in the Czech Republic to 8,6 \% in 2011. As compared to the country-wide average, the unemployment in the Osoblaha Region has constantly amounted to more than the double, and from local or seasonal perspective up to the quintuple.

Within the battle against unemployment, the municipalities of the region often make use of active employment policy, creating jobs for the unemployed through community service. Persons employed in this manner get employed at least for a part of the year, most frequently from April to October, performing cleaning, maintenance or construction works. At central level, the above stated institute was originally intended to constitute an "interchange station" between unemployment and common labour market. But in the Osoblaha Region, there is not sufficient supply of free jobs, and therefore, after terminating the time-limited agreement, the community service workers return to the register of the Employment Office. ${ }^{36}$ In other words, community service is not an "interchange station" but the "terminal station" in the Osoblaha Region. But it should be added that it is quite attractive to the unemployed. ${ }^{37}$

When conducting the research in 2013, the actual unemployment degree was ascertained in absolute figures. The Employment Office provided only a list of currently registered persons with residence in the territory of the catchment municipalities of its local branch. When comparing them with the data provided by the municipal councils of the Osoblaha Region that offered also a summary of the number of persons aged 18-65 years residing in their municipalities, the following unemployment values can be presented by 15 July 2013 (Table No. 1):

36 VAN BAAR, Huub: Socio-Economic Mobility and Neo-Liberal Governmentality in Post-Socialist Europe: Activation and the Dehumanisation of the Roma, in: Journal of Ethnic and Migration Studies, 38, 2012, 8, 12891304.

37 From the perspective of the analysis of social exclusion of the region, it must be added that the persons employed in such manner reduce de facto artificially the degree of real unemployment. 
Table No. 1: Summary of absolute number of unemployed persons in Osoblaha Region by 15 July $2013^{38}$

\begin{tabular}{|l|l|l|l|}
\hline Municipality & $\begin{array}{l}\text { Number } \\
\text { of persons } \\
\text { aged } \\
18-65 \text { years }\end{array}$ & $\begin{array}{l}\text { Number of persons registered at the } \\
\text { Osoblaha centre of the Employment } \\
\text { Office (number of persons employed } \\
\text { in community service) }\end{array}$ & $\begin{array}{l}\text { Percentage of registered persons as } \\
\text { compared to persons aged 18-65 } \\
\text { years (percentage including persons } \\
\text { employed in community service) }\end{array}$ \\
\hline Bohušov & 285 & $20(21)$ & $7,02 \%(14,39 \%)$ \\
\hline Dívčí Hrad & 188 & $12(10)$ & $6,38 \%(11,7 \%)$ \\
\hline Hlinka & 85 & $32(16)$ & $37,65 \%(56,47 \%)$ \\
\hline Osoblaha & 752 & $115(18)$ & $15,29 \%(17,69 \%)$ \\
\hline Rusín & 99 & $12(5)$ & $12,12 \%(17,17 \%)$ \\
\hline $\begin{array}{l}\text { Slezské } \\
\text { Pavlovice }\end{array}$ & 236 & $25(11)$ & $7,58 \%(15,66 \%)$ \\
\hline $\begin{array}{l}\text { Slezské } \\
\text { Rudoltice }\end{array}$ & 396 & $30(32)$ & $15,25 \%)$ \\
\hline
\end{tabular}

Source: portal.mpsv.cz, data from the Employment office - regional centre of Krnov, data from municipalities, own graphics

Another indicator of social exclusion concerns insufficient infrastructure of services. Social services are missing in general. ${ }^{39}$ Commercial and leisure-time services were also repeatedly evaluated as insufficient by the respondents (they demanded for example hairdresser's and craftsman's services and cultural opportunities). The situation is partially caused by lack of qualified staff in peripheral regions of the Czech Republic. That is related to limited educational structure of the Osoblaha Region. According to the statistics of the Census 2011, persons with apprenticeship certificate without secondary school-leaving exam prevail, and the number of persons with university education is completely negligible.

38 The table values are modelled for the season of the lowest unemployment. The third column of the table shows absolute numbers of the persons reported; the fourth column of the table shows values in which the persons employed in community service are merged with unemployed persons, as an indicator of the relative number of people directly reliant on the support of the welfare state in the area of passive and active employment policy. An even more detailed picture of the degree of unemployment support provided by the state could be obtained when adding other forms of subsidy, i.e. relief for different jobs, to the above stated summaries. But their detection would be relatively difficult and without significant heuristic effect for the purpose of this study.

39 At the time of the study, a network of basic social services was developed, based on community planning, particularly for children and youth, families with children and for persons tormented by financial problems. 
Chart No. 1: Educational structure of individual municipalities according to SLDB in 2001

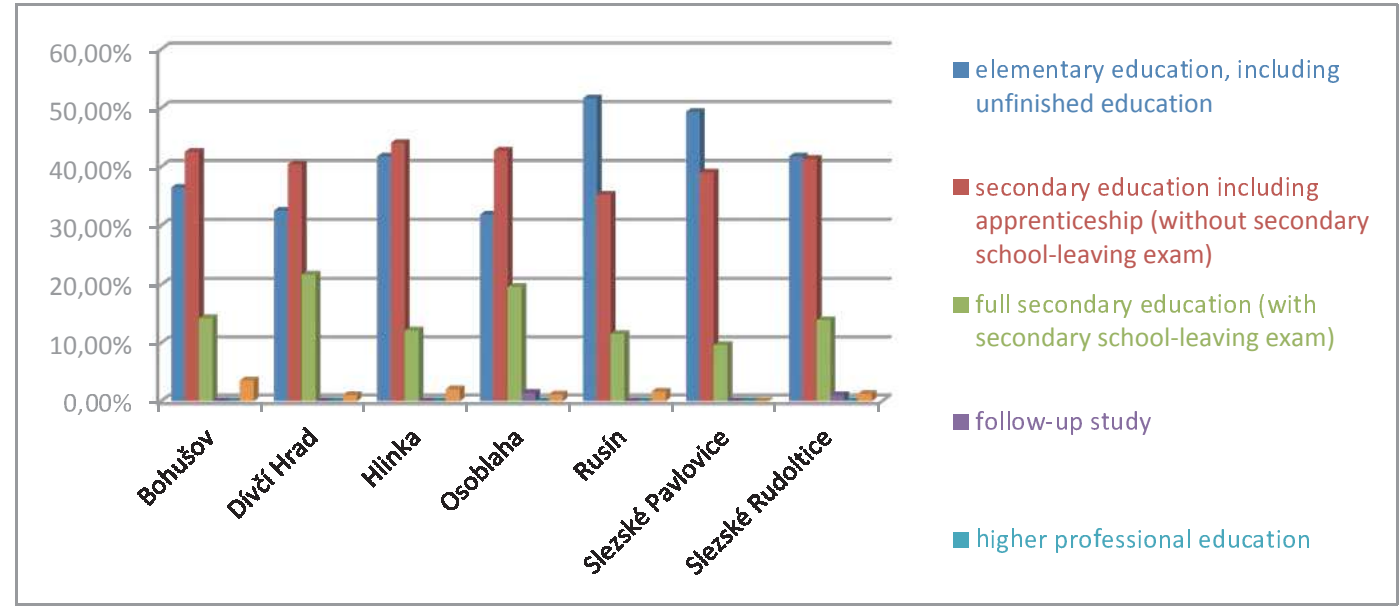

Source: Public database of ČSÚ; own graphics

Chart No. 2: Educational structure of individual municipalities according to SLDB in 2011

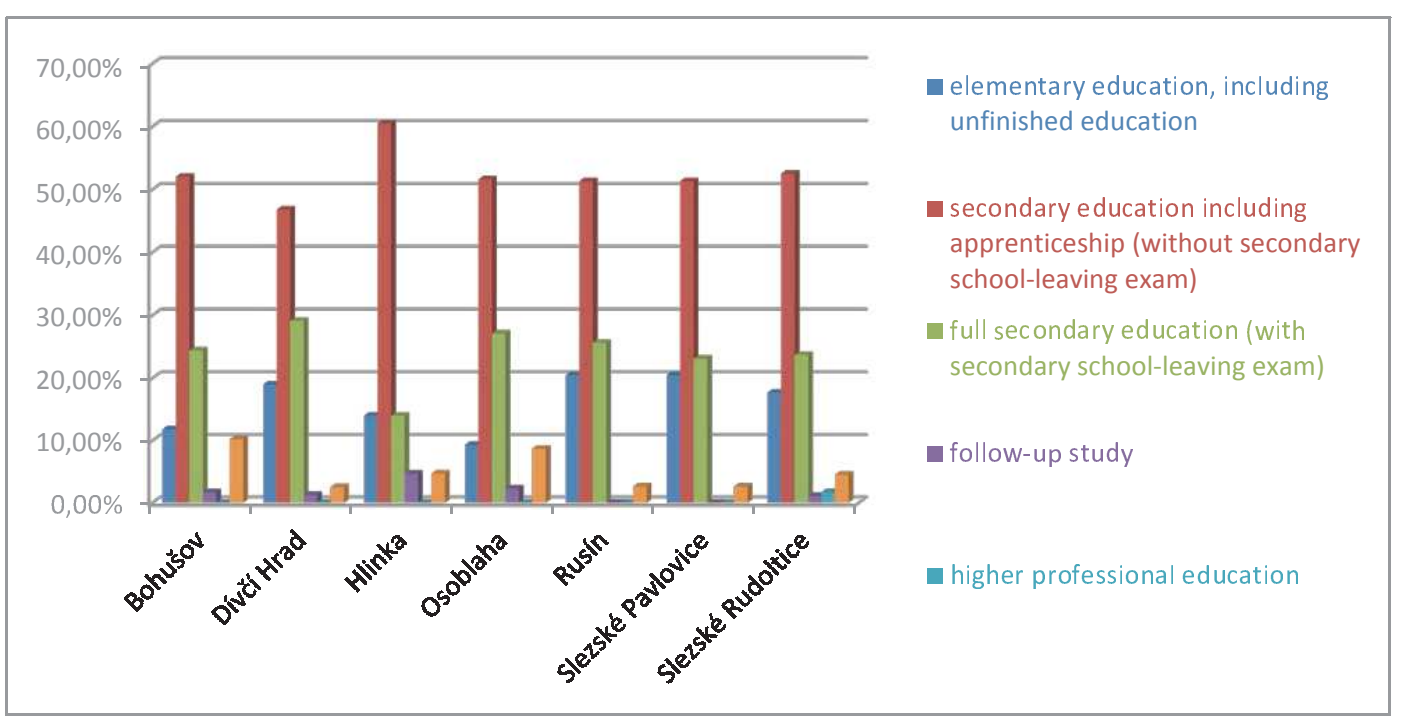

Source: Public database of Čsú; own graphics

The charts documenting in relatively detailed manner the educational structure should be completed with field comments according to which educated young people's permanent 
address at their parents' home is only formal, as they really live in other places, i.e. in urban centres with better job opportunities, which is common also in other areas. ${ }^{40}$ Therefore the actual level of this subcategory will probably lower, although it is hard to quantify. If completing the statistics by the view of employers, four out of 10 local business persons complained about low qualification of workforce as a significant factor preventing business activity. ${ }^{41}$

Social exclusion of the Osoblaha Region can be measured also with the help of the transport services indicator. The next town offering sufficient range of public services is Krnov, at 34 $\mathrm{km}$ from Osoblaha. As Krnov is an extended authority municipality, the inhabitants of the region arrange for their official documentation (identity cards, passports, etc.) in that town. The direct travel by a bus of the Osoblaha Transport Company, the only one regional bus carrier, takes 73 minutes and the passenger covers $43 \mathrm{~km}$ in total. The railway transport situation is similar; the Třemešná ve Slezsku - Osoblaha line consists of a narrow gauge railway and no direct connection is between Osoblaha and Krnov. Therefore a travel to Krnov takes 72 minutes and the total route is $34 \mathrm{~km} .{ }^{42}$

Transport accessibility was identified as a problem not only in the questionnaire inquiry performed among the inhabitants, but it was also pointed out by business persons both inside and outside the region. The problematic transport services constituted one of the causal factors of departure of a significant employer from the region and it also was the key cause of failure of the business intention in the area of waste sorting, as the regional business persons report:

We could have an order for 10 persons: I will bring some cans and waste to you and you will sort them. So we wanted to implement it here, in Osoblaha, but we were not able to work out the logistic costs, the hundred kilometres - fifty here, fifty back. The people would be interested in it, it was a perfect activity. (...) But we didn't work out the transport costs. It failed here, unfortunately. (...) It can be implemented in a bigger municipality along the transport route, but not here. ${ }^{43}$

Socially excluded localities were identified in Osoblaha, Slezské Pavlovice and Hlinka, based on the survey performed among local inhabitants, representatives of municipal self-government, as well as of other regional institutions, and during own observation in the region (bad condition of housing stock, contact with the residents). The three localities are characterized by extremely high unemployment, drawing of social benefits, low educational structure, poverty and indebtedness, as well as by stigmatization of the localities as dangerous and dirty. ${ }^{44}$

40 DRBOHLAV - RÁKOCZYOVÁ, 2012, 37-38.

41 That corresponds with the results of the questionnaire inquiry performed among the mayors of Czech rural municipalities where "insufficient human or social capital" was identified as the biggest threat to municipal development See: CHROMÝ, Pavel - JANČÁK, Vít - MARADA, Miroslav - HAVLíČEK, Tomáš: Venkov - žitý prostor: regionální diferenciace percepce venkova představiteli venkovských obcí v Česku, in: Geografie, 116, 2011, 1, 39.

42 IDOS [online]. jizdnirady.cz [quot. 05. 07. 2014]. Available at: http://jizdnirady.idnes.cz/vlakyautobusymhdvse/ spojeni/

43 The interview was held on 14 July 2013 by D. Janák and M. Pilát.

44 For details on link of symbolical inequalities to spatial inequalities, see: RUŽıČKA, Michal: Geografie sociální 
The largest excluded locality can be found in Osoblaha at the Hlavní Street. It includes eight blocks of flats with total number of 108 housing units, owned by a private owner living outside the region and managing the rental housing through a local administrator. We can distinguish three groups of population in the locality. The smallest group consists of clients of Harmony, a regional state-funded institution providing services to mentally handicapped persons. Twelve clients are temporarily accommodated in three housing units; the clients should later move to a sheltered-housing building that is under construction at several dozens of meters from the locality, at the Slunečná Street..$^{45}$ The remaining two groups can be generally characterized as unemployed and indebted clients of social services. Local actors distinguish them usually based on their ethnic origin; Romani people are presented as persons facing extreme social exclusion from the labour market. According to the statement of an employee of the department of material poverty of local Employment Office centre, many families have no adult member working. ${ }^{46}$

In Slezské Pavlovice, the excluded locality overlaps spatially with a house situated almost in the centre of the municipality, at the main road running towards the municipality. The block of flats No. 113 is inhabited by Romani ethnic group members. The last excluded locality includes blocks of flats No. 50,52, 53, 62 and 63 in the municipality of Hlinka. While the first three blocks of flats are owned by the municipality of Hlinka, the housing units of the buildings No. 62 and 63 either belong to the persons living in them, or to third persons renting them. As for the population composition, it is a homogeneous group consisting ethnically of the majority part of the society and of several Romani families that are not separated from the others.

Social distance between the inhabitants of the excluded localities and the surrounding citizens could be distinctively seen in the questionnaire inquiry and in the interviews. ${ }^{47}$ Although stigmatization was noticed in all localities under discussion, it was distinctively related to Romani ethnicity in Osoblaha and Slezské Pavlovice. The following fragment from the interview with an inhabitant of the Osoblaha Region who related the Romani immigration to former arrival of the Greeks to the region demonstrates it:

The Greeks went back home and they gave us the Gipsies instead of the Greeks. And that is a misfortune, oh guys. They hide them here from all over the republic. They have made a ghetto from our place. They will steal us everything. They have stolen so many things from me already. They have robbed my house eight times already... The people from the town want to get rid of them. ${ }^{48}$

exkluze, in: Sociální studia, 3, 2006, 2, 117-132; STEINFÜHREROVÁ, Annett: Sociálně prostorové struktury mezi setrvalostí a změnou. Historický a současný pohled na Brno, in: Sociologický časopis/Czech Sociological Review, 39, 2003, 2, 169-192.

45 Such "premature" accommodation was aimed at gradual integration of the clients into surrounding environment, as well as at preparation of local inhabitants for contact with persons with mental handicap of some degree.

46 Exact quantification is impossible; the number of persons in the locality of the Romani ethnic group keeps changing, some of them "are only visiting". So we rely on the estimates of the representatives of local selfgovernments and of the Employment office Employees.

47 It can be seen e.g. in negative answers of the inhabitants to questions like: "Are you on speaking terms with people from that locality?"; "Do you have a friend among people from that locality?"; "Do people from the locality mix with others at public social events?", etc.

48 The quote from the interview from Slezské Pavlovice divides the immigrants explicitly into the Romani and the 


\begin{tabular}{l|ll|l}
\hline 130 & $\begin{array}{c}\text { ARTICLES } \\
\text { Dušan JANÁK, jr. - Jan BEzǒ̌K - Václav WALACH }\end{array}$ & $\begin{array}{c}\text { Social Exclusion Under the Auspices of the State? Gase Study of } \\
\text { Social Exclusion, Ethnicity and Migration in Osoblaha Region }\end{array}$ \\
\hline
\end{tabular}

Similarly to the Šluknov Region ${ }^{49}$ and other peripheral areas, the concentration of great number of "foreign" Romani people in the Osoblaha Region was also commented with reference to increasing minor criminality. And similarly to other cases, the relation is also rather a matter of public opinion than that of knowledge, and so it cannot be excluded that, rather than reflecting the actual minority behaviour, it reflects the stereotyped majority perception of the Romani as "asocial individuals" and "criminals", nurtured and supported by different rumours. ${ }^{50}$ Anyhow, the "Romani criminality", conceived anthropologically as a myth ${ }^{51}$, contributes undoubtedly to some degree to deepening of mutual mistrust and strengthening of symbolical frontiers between both groups.

The inter-ethnic tensions are of course reflected also in the reactions of the stigmatized group. Not only the person quoted below, but also other inhabitants of socially excluded localities disapproved their stigmatization bordering on criminalization. To the question how he perceived the complaints of the surrounding inhabitants about too loud gatherings of socially excluded persons in front of their houses, he answered:

Well, if they don't do anything there and if they are only sitting there and there are only children playing and it is afternoon, well, I don't know why somebody is annoyed if they are outside. If they are in the house, they are annoyed that they are in the house. If you go out, they are annoyed too. So perhaps we only should be closed in a fence, or I don't know where we should go. They are annoyed by just everything (...) Even if you don't do anything and want to behave well, it is wrong. So better be a bastard, and you will be at peace, don't you? If it cannot work either by hook or by crook, so I don't know what to do. They want to have you here to hang you out, or I don't know. ${ }^{52}$

But the relatively positive attitudes towards the Romani people, which were recorded, although only towards the Romani people as a whole and not specifically towards "the new ones" suggest that this myth is not insurmountable. The statements of some employers, municipal representatives and inhabitants of socially excluded localities with positive experiences can lead to a basic principle to overcome the mutual mistrust - by learning to know each other through more intensive social contacts, including contacts controlled "from above". An inhabitant of an excluded locality of Osoblaha who deems the interethnic tension an exaggerated, factually unreal problem, describes it as follows:

Greeks. The interview was held in July 2013 by D. Janák, J. Bezděk, M. Pilát.

49 Události ve Šluknovském výběžku [online], Praha: Ministerstvo vnitra, 2011 [cit 1. 12. 2014], dostupné z: http://www.mvcr.cz/soubor/udalosti-ve-sluknovskem-vybezku-k-pdf.aspx.

50 Compare: DRBOHLAV - RÁKOCZYOVÁ, 2012, 12; TOPINKA, Daniel - JANOUŠKOVÁ, Klára (eds.): Výzkum rizikových faktorů souvisejících s existencí sociálně vyloučených romských lokalit ve městě Přerově, Ostrava 2009, 200-201; WEINEROVÁ, Renata: Anti-Gypsyism in the Czech Republic: Czechs'Perception of Roma in Cultural Stereotypes, in: Acta Ethnographica Hungarica, 59, 2014, 1, 214-215. The increasing criminality was confirmed by the figures provided by the Czech Police, but it cannot be ascertained whether it was or was not committed by the Romani people. In any case, starker opinions of the public could be registered both in the interviews and for example in three focus groups (in which J. Bezděk took part) held in spring 2013 within the activities of the Local Partnership Criminality Prevention working group.

51 LÉVI-STRAUSS, Claude: Mýtus a význam, Bratislava 1993.

52 The interview was held by J. Bezděk in July 2013. 
The interviewer (hereinafter referred to only as "I"): "Are you considering some change of scene?

Respondent (hereinafter referred to only as "R"): Definitely not. Even if I lose my job, which I probably will, as I have a contract only for a year, I am not considering it. My children are accustomed to live here already and they are satisfied. I have founded X (anonymized), which I love, and I would not go away just for these two reasons. The accessibility is good here, and the people are somehow more open, different. There are some racial problems, yes, but they seem artificial to me.

I: Artificial, in what sense?

R: Artificially created racism. People are imagining something that is not here at all. I: What people do that, in your view? Why do you think people are imagining this? R: They are mostly afraid. They are afraid of the unknown. Mainly the non-Romani inhabitants are afraid of the Romani people, as they don't know them. They know me already, and that's why they say that I am not Romani, that I am theirs. That is only due to the fact that they have learned to know me.

I: So you say that people must learn to know each other?

R: Yes.

I: And what would you suggest for the people to learn to know the Romani people better?

R: More social events, more social events.

I: And what if one group does not arrive to the event.

$R$ : The citizens must be invited to learn to know each other. For example now, there was a volleyball tournament, foot tennis and tennis. Our boys came from there and they were enthused by having learned to know so many people, including people who are important here. On the other hand, also the non-Romani people say positive things about them, stating that they are not the way they look, and they only had to play some games together." ${ }^{53}$

\section{Share of state in development of social exclusion of the Osoblaha Region}

Nevertheless, this study is not aimed at solving the problem of social inclusion of ethnically stigmatized groups but at trying to identify the factors of social exclusion of the Osoblaha Region articulated by our respondents whom we perceive as people disposing of local understanding, within the integrated strategy. When seeking the causes of the current adverse situation of the region, the awareness of the inhabitants reflects both historical circumstances and recent events, with common denominator consisting in the crucial importance of the state and public policies in the area of shaping and reproducing the situation.

From historical perspective, we can distinguish three events that predetermined the character of the current situation of the region: First, the postwar displacement of the German population due to so called Beneš Decrees. Second, the collectivization of

53 The interview was held by J. Bezděk in July 2013. 
agriculture and creation of a new economic organization - so-called state farm. Third, change of regime in 1989 and the related privatization of state property. Migration is the accompanying feature of all those changes, and it is understood by local inhabitants as migration with ethnic character. ${ }^{54}$ To show the historical awareness, we use the extracts from two interviews, one held with a native from Osoblaha, and the other with an inhabitant who moved in only several years ago:

They say that everything is broken here, broken cowshed, and so on. We now reap the communist harvest. All the mess that is here, and also in the republic, all that is communist harvest. It is as if you plant a wilding somewhere and it brings bad fruit, so that is the system we have here. They expelled three million Germans and Beneš yelled: "We must expel the Germans, even if the borderlands becomes overgrown with nettles." And now we have it. Guys, I tell you something. The collectivization affected the whole ecology, the whole nature. ${ }^{55}$

[T]he Sudetenland, that was the start of the whole problem... The displacement of the Germans... I ... Everybody who are doing more or less well and have some German ancestors condemn strictly the displacement of the Germans... I tell them to get wise a little, to rip off the blindfold. (...) By that [displacement], people compensated the revenge on the Sudeten Germans. I am just able to imagine myself in their shoes. The events that came then were worse. When the communists won and started doing their social experiments here. (...) I don't know anything about the dark period of the 1950s, I don't know what happened here. Rather from the period I have experienced [although not in the Osoblaha region, author's comment] and could observe, there is the agriculture that originated here. There was a state farm and a unified cooperative farm. (...) The year 1989 deprived the people here of work, and therefore of their whole life, because the unified farm had cared of everything here (...), of work and of leisure time. ${ }^{\prime \prime 6}$

The problem of the historical roots was opened by both communication partners without any goal-directed question, just at the beginning of the interview that was primarily aimed at the attractiveness of the region from the perspective of business activities, without inquiring into its past. Other interviews also reflected historical context, particularly in relation to the liquidation of the state farm that had been absolutely key employer of both local and non-resident persons who had moved here for working reasons, and it had also organized the extracurricular life of the region. ${ }^{57}$ An indirect but relatively obvious evidence of it can be seen in the election preferences of the inhabitants of the Osoblaha region,

54 The displaced Germans and other agricultural workers were replaced by war refugees from Greece. On the other hand, current period is characterized by Romani immigration. Compare: BURTON - GARRETT-PETERS MAJOR EASON, 2011.

55 The interview was held on 2 July by D. Janák, J. Bezděk, M. Pilát.

56 The interview was held by D. Janák on 1 July 2013.

57 The positive evaluation of the state farm era as compared to current situation could be heard more frequently in interviews held with employees than in those held with business persons. 
summarized in Table No. 2. The survey of the votes obtained by individual political parties in the municipalities of the region clearly documents the persisting electoral preferences favouring left-wing parties (ČSSD, KSČM). On the contrary, the KDU-ČSL party, traditionally stronger in agricultural regions, has rather few electors in the Osoblaha Region.

Table No. 2: Proportional survey of votes obtained by individual political parties in individual years and municipalities in the elections to the Chamber of Deputies

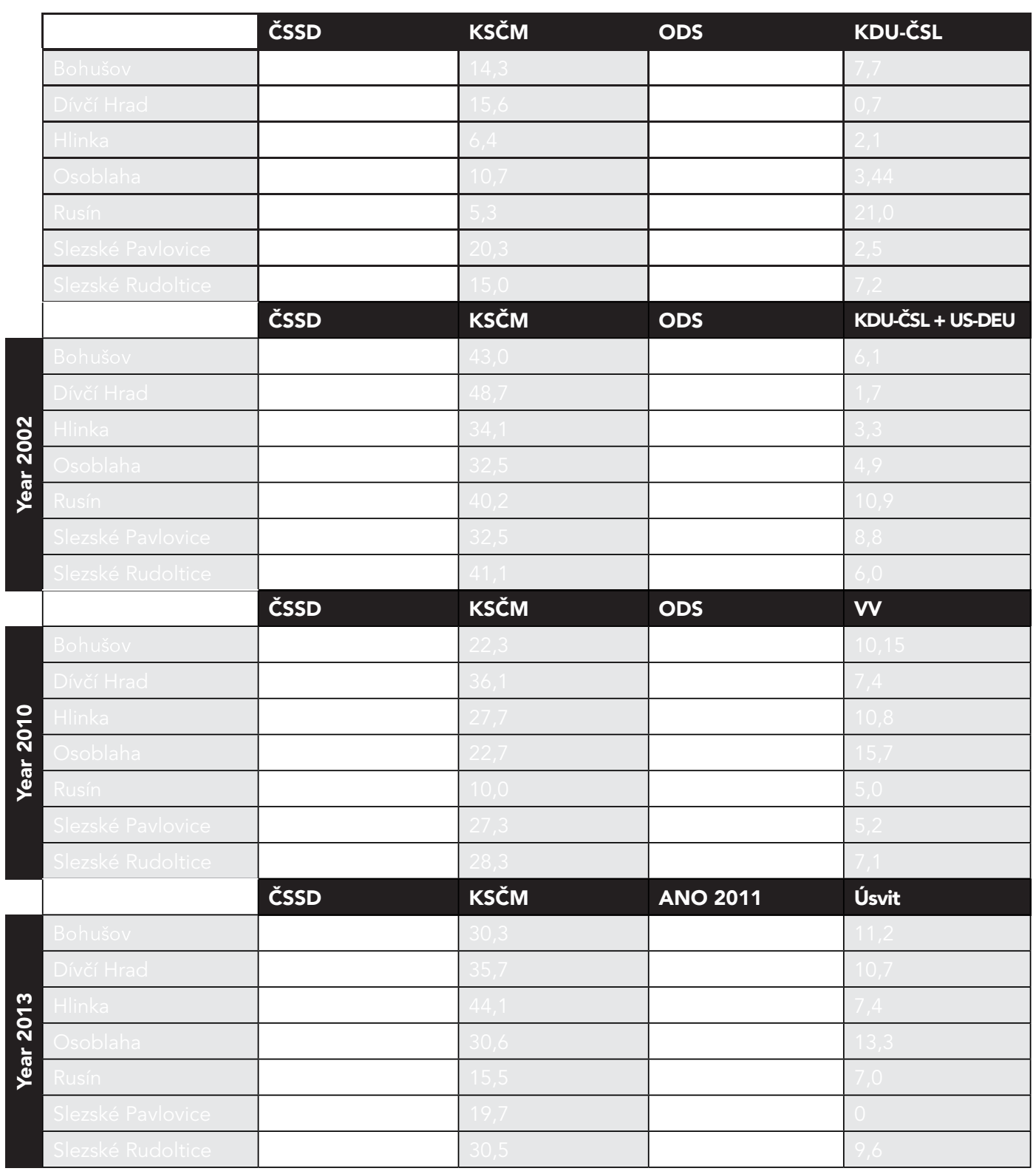

source: www.volby.cz, own graphics 
But the analysis of remembering the period before 1989 will not be complete without identifying the significance of the ambivalence and contradictoriness in evaluation of the historical events. It is clearly reflected in the second extract quoted. It can be seen in the hesitation when defining oneself and when seeking a manner to explain the causes of the current crisis situation to a stranger-researcher. From the current perspective, "communism", imposed by the state system, is once a "villain" (that expelled the Sudeten Germans and collectivized the agricultural production) and the other time a "hero" (that provided working and extracurricular opportunities). Anyhow, the change of the regime had, according to the respondent, fatal consequences on the inhabitants of the region who, due to restructuring of the economy, were deprived not only of work but of their "whole life" and have predominantly sceptical attitudes to a potential upturn.

The standard of living in the Osoblaha Region depends strongly on the decisions made in the republic centre, both with regard to the level of support of agricultural activities (subsidies to farmers) or to redistribution to persons in need within welfare state. In spite of the declared effort to support disadvantaged regions, we can see preference for developed regions in allocation of public resources ${ }^{58}$, which has consequences not only to local agricultural business persons and their employees but also to those who, due to structural unemployment, had landed on the margin of the society.

This issue includes also social policy in residential area. Missing law on "social" housing, persisting discrimination in the residential market and the legally tolerated "social exclusion industry ${ }^{\prime \prime}{ }^{59}$ based on speculations in providing welfare beneficiaries with relatively more expensive or overpriced housing, as well as the existence of special welfare beneficiaries, constitute the basic ground on which the issue of socially excluded localities has grown, among other things. ${ }^{60}$

That is the background of the Romani migration to the Osoblaha Region, mentioned many times by the respondents; according to local inhabitants, it started approximately in 2010. The number of such Romani immigrants is, according to qualified estimate, 250 persons. ${ }^{61}$ At present, they are concentrated mainly in the above stated socially excluded locality of Osoblaha. But it cannot be ruled out that the same situation will occur also in other localities of the Osoblaha Region, or that it has occurred already (e.g. in Slezské Pavlovice, at lower degree). According to the respondents from the Employment Office and from the municipal councils, they arrive to find more affordable housing, from Bruntál, Šumperk, Rýmařov, Krnov and other cities of the Moravian-Silesian Land. And the same finding is confirmed also by our interviews with the inhabitants of the excluded localities.

58 BLAŽEK, Jiří - MACEŠKOVÁ, Marie: Regional Analysis of Public Capital Expenditure: To which Regions is Public Capital Expenditure Channelled - to "Rich" or to "Poor" Ones?, in: Regional Studies, 44, 2010, 6, 679-696.

59 TOŠNER, Michal et al: Průmysl sociálního vyloučení. Lokalita Janov, in: AntropoWebzin, no. 1, 2010,17 - 32.

60 Compare: LUX, Martin - MIKESZOVÁ, Martina - SUNEGA, Petr: Podpora dostupnosti bydlení pro lidi akutně ohrožené sociálním vyloučením - mezinárodní perspektivy a návrhy opaření v ČR, Praha 2010; RŮŽlČKA, 2006; RŮŽIČKA - LUPTÁK, 2013.

61 That figure from the quoted analysis is confirmed also by our findings based on the interviews with the employees of the authorities and with the inhabitants. The quantification of the Romani immigrants is complicated mainly by the factor of high fluctuation and migration variation. The following pattern was described: early in a month, an apartment is rented to a family that leaves it late in the next month, and the apartment is rented to another immigrating family by its private owner. Compare: NOVÁK, 2012 
The following quotation shows a part of the answer to the question: What has brought you to the Osoblaha Region?

It can be said that the housing policy (...) offers better comfort, better housing conditions, as in the place where I come from - the Jeseník Region - has high housing costs, heating costs, and also bad accessibility.

When getting housing in the Osoblaha Region, personal contacts play a significant role. The fact which families will move here is influenced by exchange of information within the social networks among the individuals living here already and the individuals who are going to move here. The following quotation evidences the above stated words:

Well, first I got it by arranging this sublease through a friend. We have a sublease here, actually. (...) We have been here for three, four years... The fourth year. I am always mixing it up. The year, you know, 2009 or 2010... And housing... housing is good here, people can live here well. I was in England. And then I needed a sublease, so I ... As I said, through that friend of mine, he told me that that guy was renting apartments, so I went to see him and arranged it with him.

But paradoxically, people in private apartments in Osoblaha, made free due to the descending demographic curve and to depopulation of rural areas in favour of urban areas, pay twice as much as in council flats of the same category. ${ }^{62}$ That, understandably, deepens the social exclusion as the housing costs usually constitute the largest item of the budget of the inhabitants of the excluded locality. As a result, such differentiation causes strengthened spatial and symbolical inequalities. While poor immigrants concentrate in private buildings, local inhabitants make use of their contacts to escape from the apartments, that lose attractiveness not only due to higher rent but also due to higher number of "strangers", to council flats (if a suitable flat is vacated). With each moved "old resident", replaced by an "immigrant", the moving spiral rotates faster and faster, the border between "the ours" and "the strangers" gets sharper and new excluded localities emerge, which can result in decreasing development potential of the region and its increasing social exclusion as a whole.

\section{Conclusion}

The Osoblaha Region can be considered disadvantaged in all areas researched. Primarily, it is significantly affected by structural unemployment. Its degree has been oscillating in the long term between 8 and $12 \%$; nevertheless, last year, it climbed to almost $38 \%$ in the municipality of Hlinka. The municipalities try to solve the situation with the help of community service that, however, constitutes only temporary alternative not continued by permanent job in common labour market.

That is related to the observed trend of inner migration towards regions with wider job

62 In Osoblaha, the price of rent in private building amounts to $50-51 \mathrm{CZK} / 1 \mathrm{~m}^{2}$; in council flat at the same street and in the same building type (block of flats from the state socialism era), it amounts to $25 \mathrm{CZK} / 1 \mathrm{~m}^{2}$. 
opportunities, which has negative impact on the low educational index of the region. Persons with secondary education without secondary school-leaving exam and elementary education (including unfinished elementary education) prevail here. The seclusion of the region and bad transport accessibility also have impact on the region's falling behind more thriving parts of the Czech Republic. When travelling by public transport, it takes more than an hour to go to the next administration centre. A specific problem consists in the existence of socially excluded localities. Such localities not only deepen the social exclusion of their inhabitants but at the same time increase social tensions among the inhabitants. Moreover, the problem is understood as ethnically defined, to considerable degree.

When uncovering the processes leading to current situation of social exclusion of the region, we proceeded from immediate causes to deeper historical connections. In that context, the crucial event for current social exclusion is seen in the displacement of the Germans from the region after World War II, as it changed fundamentally the structure of the population and of property relations. The subsequent collectivization led to a new economic organization - state farm - that was one of the biggest organizations in Czechoslovakia and offered material motivation to workers from other parts of the republic to arrive. After the Velvet Revolution, the state farm was liquidated, and as its restitution was prevented by Beneš Decrees, the agricultural land came to the property of several big farmers, so that the agriculture preserved, to some degree, the large-scale production character from the era of state socialism, only in privatized form. A great part of work in the current big farms is performed by machines that must be operated by highly qualified workers whose number, however, need not be high. Furthermore, the existing agricultural subsidy policy does not require diversification of agricultural production, and therefore leads indirectly to reduction of the number of jobs in agriculture and to increasing unemployment in the region. The former employees of the state farm remember the "good old days" of the former regime when they were fully employed; that corresponds with their election preferences in support of left-wing parties like KSČM and ČSSD.

Our study further confirmed the trend of migration of socially excluded Romani people to peripheral areas of the country. ${ }^{63}$ At present, the Osoblaha Region is coping with relatively large Romani immigration that often lands in socially excluded localities and is accompanied by strong inter-ethnic tension. The key factor of immigration consists in the price of rent. Although higher than in council flats usually inhabited by old residents, it is significantly lower as compared to housing in towns and municipalities outside the microregion. Discrimination in the labour market, opportunity to draw housing allowances and other forms of benefits, including use of the institute of special beneficiary, all these factors allow enrichment on the expense of socially excluded beneficiaries of social welfare due to their spatial concentration.

Our study showed that public policies, including their unintended consequences, are deemed an important factor in generation of social exclusion. ${ }^{64}$ Although we do not challenge

63 DRBOHLAV - RÁKOCZYOVÁ, 2012, 38; OUŘEDNÍČEK, Martin - NOVÁK, Jakub: Kvantitativní analýza stavu a vývoje segregace/separace obyvatelstva, in: Segregace v České republice: stav a vývoj, prŕčiny a důsledky, prevence a náprava, SYKORA, Luděk (ed.), Praha 2007, 17. Dostupné z: https://web.natur.cuni.cz/segregace/ images/stories/dokumenty/kapitola2.pdf.

64 KELLER, Jan: Nedomyšlená společnost, Brno 1992, 112-125; MERTON, Robert K.: The Unanticipated 
the fact that public policies constitute a crucial part of solution of social exclusion ${ }^{65}$, we suggest, with regard to future research, to examine them "not [only] as a product of social inequalities but [also] as a potential source of such inequalities" ${ }^{66}$ From the perspective of our respondents, they constitute the absolutely most important processes responsible for the current situation of the Osoblaha Region. To what degree this local finding corresponds to sociological generalization, is to be uncovered by another study.

\section{Abstract}

This study deals with a still not sufficiently studied phenomenon of social exclusion in the Czech rural regions. On the case of Osoblaha, we point out the influence of regional characteristics of social inclusion on the transformation of the region's social structure. The disadvantage of a region in the spheres of employment, education, community facilities and transport services contributes to emigration of relatively educated population able to work; such population is, to certain degree, substituted by socially excluded persons seeking relatively cheaper housing; and that contributes to increasing local social tension. Together with the analysis of the current status of social exclusion in the Osoblaha Region, based on quantitative and qualitative data, we present, as the main finding, the need of further dealing with the impact of public policies on shaping of social exclusion in excluded rural regions.

\section{Keywords}

social exclusion, Osoblaha Region, socio-economic development, ethnicity, migration, case study

\section{References}

Analýza sociálně vyloučených romských lokalit a absorpční kapacity subjektů působících $v$ této oblasti, Praha 2006.

BARŠOVÁ, Andrea: Problémy bydlení etnických menšin a trendy k residenční segregaci v České republice, in: Romové ve městě, VÍŠEK, Petr (ed.), Praha 2002, 3-42.

BERTOLINI, Paola - MONTANARI, Marco - PERAGINE, Vito: Poverty and Social Exclusion in Rural Areas. Final Study Report [online]. Brussels, Luxembourg: Directorate-General for Employment, Social Affairs and Equal Opportunities, 2008 [cit. 1. 12. 2014]. Dostupné z: http://ec.europa.eu/social/BlobServlet?docld=2087\&langld=en.

BLAŽEK, Jiř́ - MACEŠKOVÁ, Marie: Regional Analysis of Public Capital Expenditure: To which Regions is Public Capital Expenditure Channelled - to "Rich" or to "Poor" Ones?, in: Regional Studies, 44, 2010, 6, 679-696.

Consequences of Purposive Social Action, in: American Sociological Review, 1, 1936, 6, 894-904.

65 Compare e. g.: MACEŠKOVÁ - OUŘEDNíČEK - TEMELOVÁ, 2009; HORÁKOVÁ, Markéta - RÁKOCZYOVÁ, Miroslava: Sociální vyloučení a sociální začlenění v perspektivě lokálních aktérů sociální politiky, in: MAREŠ, Petr HORÁKOVÁ, Markéta - RÁKOCZYOVÁ, Miroslava: Sociální exkluze na lokální úrovni, Praha 2008, 41-75.

66 RŮŽIČKA, 2011, 275. 
BLAŽEK, Jiří - CSANK, Pavel: Nová fáze regionálního rozvoje v ČR?, in: Sociologický časopis/Czech Sociological Review, 43, 2007, 5, 945-965.

BURTON, Linda M. - GARRETT-PETERS, Raymond - MAJOR EASON, John: Morality, Identity, and Mental Health in Rural Ghettos, in: Communities, Neighborhoods, and Health. Expanding the Boundaries of Place, BURTON, Linda M. - KEMP, Susan P. - LEUNG, Manchui - MATTHEWS, Stephen A. - TAKEUCHI, David. T. (eds.), New York 2011, 91-110.

CHROMÝ, Pavel - JANČÁK, Vít - MARADA, Miroslav - HAVLÍČEK, Tomáš: Venkov - žitý prostor: regionální diferenciace percepce venkova predstaviteli venkovských obcí v Česku, in: Geografie, 116, 2011, 1, 23-45.

DAVIS, Mike: Planet of Slums, London 2007.

DRBOHLAV, Dušan - RÁKOCZYOVÁ, Miroslava: Social Impact of Emigration and Rural-Urban Migration in Central and Eastern Europe. Final Country Report: Czech Republic [online] 2012 [cit. 1. 12. 2014], dostupné z: http://ec.europa.eu/social/ BlobServlet?docld $=8850 \&$ langld $=$ en .

FLYVBJERG, Bent: Case Study, in: The Sage Handbook of Qualitative Research, DENZIN, Norman K. - LINCOLN, Yvonna S. (eds.), Thousand Oaks 2011, 301-316.

GERBERY, Daniel - DŽAMBAZOVIČ, Roman: Inovativne orientácie v sociálnej politike: Perspektíva sociálnej inklúzie, Bratislava 2011.

GORDON, David: History and Development of Social Exclusion and Policy, in: Multidisciplinary Handbook of Social Exclusion Research, ABRAMS, Dominic-CHRISTIAN, Julie - GORDON, David (eds.), Chichester 2007, 193-210.

GRYGAR, Jakub - STÖCKELOVÁ, Tereza: Př́činy a souvislosti stěhování vsetínských Romů z pavlačového domu č.p. 1336 v říjnu 2006, Brno 2007.

HAMPL, Martin: Regionální diferenciace současného socioekonomického vývoje v České republice, in: Sociologický časopis/Czech Sociological Review, 43, 2007, 5, 889-910.

HAVLÍČEK, Tomáš - CHROMÝ, Pavel - JANČÁK, Vít - MARADA, Miroslav: Vybrané teoreticko-metodologické aspekty a trendy geografického výzkumu periferních oblastí, in: Problémy periferních oblastí, NOVOTNÁ, Marie (ed.), Praha 2005, 6-24.

HIRT, Tomáš - JAKOUBEK, Marek: „Romové" v osidlech sociálního vyloučení. Plzeň 2006. HORÁKOVÁ, Markéta - RÁKOCZYOVÁ, Miroslava: Sociální vyloučení a sociální začlenění v perspektivě lokálních aktérů sociální politiky, in: MAREŠ, Petr - HORÁKOVÁ, Markéta RÁKOCZYOVÁ, Miroslava: Sociální exkluze na lokální úrovni, Praha 2008, 41-75.

JANÁK, Dušan: Brněnská versus pražská sociologická škola: mýtus a skutečnost, in: Sociologický časopis/Czech Sociological Revue, 49, 2013, 4, 577-602.

JANÁK, Dušan - PILÁT, Miroslav - BEZDĚK, Jan: Rozdělování sociálních nerovností pod patronací státu. Situační analýza Osoblažska a možností jeho socioekonomického rozvoje, Opava 2014.

KELLER, Jan: Nedomyšlená společnost, Brno 1992.

KELLER, Jan: Nová sociální rizika a proč se jim nevyhneme, Praha 2011.

KUBEŠ, Jan - KRAFT, Stanislav: Periferní oblasti jižních Čech a jejich sociálně populační stabilita, in: Sociologický časopis/Czech Sociological Review, 47, 2011, 4, 805-829.

LÉVI-STRAUSS, Claude: Mýtus a význam, Bratislava 1993.

LEVITAS, Ruth: The Inclusive Society? Social Exclusion and New Labour, Basingstoke 2005.

LOUČKOVÁ, Ivana: Integrovaný přístup v sociálně vědním výzkumu, Praha 2010. 
LUPTÁK, Ĺubomír a kol.: Neoliberalismus a marginalita: studie z českého reálkapitalismu, Brno 2013.

LUX, Martin - MIKESZOVÁ, Martina - SUNEGA, Petr: Podpora dostupnosti bydlení pro lidi akutně ohrožené sociálním vyloučením - mezinárodní perspektivy a návrhy opaření v ČR, Praha 2010.

MACEŠKOVÁ, Marie - OUŘEDNÍČEK, Martin - TEMELOVÁ, Jana: Sociálně prostorová diferenciace v České republice: implikace pro veřejnou (regionální) politiku, in: Ekonomický časopis, 57, 2009, 7, 700-715.

MAJEROVÁ, Věra: Český venkov 2008 - proměny venkova, Praha 2009.

MAREŠ, Petr: Faktory sociálního vyloučení, Praha 2006.

MAREŠ, Petr: Prostorové aspekty sociální exkluze, in: MAREŠ, Petr - HORÁKOVÁ, Markéta - RÁKOCZYOVÁ, Miroslava: Sociální exkluze na lokální úrovni, Praha 2008, 9 - 42.

MAREŠ, Petr - SIROVÁTKA, Tomáš: Sociální vyloučení (exkluze) a sociální začleňování (inkluze) - koncepty, diskurz, agenda, in: Sociologický časopis/Czech Sociological Review, 44, 2008, 2, 271-294.

MAREŠ, Petr: Marginalizace, sociální vyloučení, in: Menšiny a marginalizované skupiny v České republice, SIROVÁTKA, Tomáš (ed.), Brno 2002, 9-24.

MASSEY, Douglas S. - DENTON, Nancy A.: American Apartheid: Segregation and the Making of the Underclass, Cambridge 1993.

MERTON, Robert K.: The Unanticipated Consequences of Purposive Social Action, in: American Sociological Review, 1, 1936, 6, 894-904.

MILLAR, Jane: Social Exclusion and Social Policy Research: Defining Exclusion, in: Multidisciplinary Handbook of Social Exclusion Research, ABRAMS, Dominic-CHRISTIAN, Julie - GORDON, David (eds.), Chichester 2007, 1-16.

MUSIL, Jiří: Regionální a místní formy sociálního vyloučení a jak jim čelit - problém vnitřních periferií v České republice, in: Sociální vyloučení a sociální politika, SIROVÁTKA, Tomáš (eds.), Brno 2006, 25-40.

MUSIL, Jiří - MÜLLER, Jan: Vnitřní periferie v České republice jako mechanismus sociální exluze, in: Sociologický časopis/Czech Sociological Review, 44, 2008, 2, 321-348.

MUSTERD, Sako: Social and Ethnic Segregation in Europe: Levels, Causes, and Effects, in: Journal of Urban Affairs, 27, 2005, 3, 331-348.

NOVÁK, Karel A.: Analýza přihlášky obce Osoblaha, Praha 2012.

OUŘEDNÍČEK, Martin - NOVÁK, Jakub: Kvantitativní analýza stavu a vývoje segregace/ separace obyvatelstva, in: Segregace v České republice: stav a vývoj, př́činy a důsledky, prevence a náprava, SÝKORA, Luděk (ed.), Praha 2007, 9-28. Dostupné z: https://web. natur.cuni.cz/segregace/images/stories/dokumenty/kapitola2.pdf.

PERLíN, Radim - KUČEROVÁ, Silvie - KUČERA, Zdeněk: Typologie venkovského prostoru Česka, in: Geografie, 15, 2010, 2, 161-187.

RŮŽIČKA, Michal: Geografie sociální exkluze, in: Sociální studia, 3, 2006, 2, 117-132.

RŮŽIČKA, Michal: Urbanizace chudoby a etnicity v socialistickém a (post)socialistickém městě, in: Československé město včera a dnes: každodennost, reprezentace, výzkum, VACKOVÁ, Barbora - FERENČUHOVÁ, Slavomíra - GALČANOVÁ, Lucie (eds.), Červený Kostelec 2010, 137-158.

RŮŽIČKA, Michal: Časoprostorové a infrastrukturní aspekty procesu sociální exkluze, in: 
Sociologický časopis/Czech Sociological Review, 47, 2011, 2, 273-295.

RŮŽIČKA, Michal - LUPTÁK, L'ubomír: Těžební limity prolomeny: Extrakce ekonomického a politického kapitálu z romského ghetto, in: LUPTÁK, Ĺubomír a kol.: Neoliberalismus a marginalita: studie z českého reálkapitalismu, Brno 2013, 192-207.

RŮŽIČKA, Michal - TOUŠEK, Ladislav: Sociální exkluze: její prostorové formy a měnící se podoby, in: ŠUBRT, Jiř́ a kol.: Soudobá sociologie VI (Oblasti a specializace), Praha 2014, 117-141.

SHLUCKSMITH, Mark: Class, Power and Inequality in Rural Areas: Beyond Social Exclusion?, in: Sociologia Ruralis, 52, 2012, 4, 377-397.

SHLUCKSMITH, Mark: Social Exclusion in Rural Areas: A Review of Recent Research, London 2004.

SIBLEY, David: Geographies of Exclusion: Society and Difference in the West, London, New York 1995.

STEINFÜHREROVÁ, Annett: Sociálně prostorové struktury mezi setrvalostí a změnou. Historický a současný pohled na Brno, in: Sociologický časopis/Czech Sociological Review, 39, 2003, 2, 169-192.

STEWART, Kitty: Monitoring Social Inclusion in Europe's Regions, in: Journal of European Social Policy, 13, 2003, 4, 335-356.

Strategie sociálního začleňování 2014-2020, Praha 2014.

ŠIMÍKOVÁ, Iva - VAŠEČKA, Imrich (eds.): Mechanismy sociálního vyčleňování romských komunit na lokální úrovni a nástroje integrace, Brno 2004.

TEMELOVÁ, Jana - NOVÁK, Jakub - POSPIŚIILOVÁ, Lucie - DVOŘÁKOVÁ, Nina: Každodenní život, denní mobilita a adaptační strategie obyvatel v periferních lokalitách, in: Sociologický časopis/Czech Sociological Review, 47, 2011, 4, 831-858.

TOPINKA, Daniel - JANOUŠKOVÁ, Klára (eds.): Výzkum rizikových faktorů souvisejících s existencí sociálně vyloučených romských lokalit ve městě Přerově, Ostrava 2009.

TOŠNER, Michal et al: Průmysl sociálního vyloučení. Lokalita Janov, in: AntropoWebzin, no. 1, 2010, 17 - 32 .

TOUŠEK, Ladislav: Kultura chudoby, underclass a sociální vyloučení, in: "Romové" v osidlech sociálního vyloučení, HIRT, Tomáš - JAKOUBEK, Marek (eds.), Plzeň 2006, 288-321.

Události ve Šluknovském výběžku [online], Praha: Ministerstvo vnitra, 2011 [cit 1. 12. 2014], dostupné z: http://www.mvcr.cz/soubor/udalosti-ve-sluknovskem-vybezku-k-pdf.aspx.

VAN BAAR, Huub: Socio-Economic Mobility and Neo-Liberal Governmentality in PostSocialist Europe: Activation and the Dehumanisation of the Roma, in: Journal of Ethnic and Migration Studies, 38, 2012, 8, 1289-1304.

WACQUANT, Loïc: Urban Outcasts. A Comparative Sociology of Advanced Marginality, Cambridge 2008.

WEINEROVÁ, Renata: Anti-Gypsyism in the Czech Republic: Czechs'Perception of Roma in Cultural Stereotypes, in: Acta Ethnographica Hungarica, 59, 2014, 1, 211-221.

WINKLER, Jiří - KLIMPLOVÁ, Lenka: Nová sociální rizika na trhu práce a potřeby reformy české veřejné politiky, Brno 2010. 